\title{
Balkanologie
}

Balkanologie Revue d'études pluridisciplinaires

Vol. VIII, $n^{\circ} 1$ | 2004

Volume VIII Numéro 1

\section{Turkish policy towards the conflict in Kosovo: the preeminence of national political interests}

La politique de la Turquie dans le conflit du Kosovo : les pré-éminence des intérêts (politiques) nationaux

\section{Sylvie Gangloff}

\section{OpenEdition}

\section{Journals}

Édition électronique

URL : http://journals.openedition.org/balkanologie/517

DOI : 10.4000/balkanologie.517

ISSN : 1965-0582

Éditeur

Association française d'études sur les Balkans (Afebalk)

Édition imprimée

Date de publication : 1 juin 2004

ISSN : 1279-7952

\section{Référence électronique}

Sylvie Gangloff, «Turkish policy towards the conflict in Kosovo: the preeminence of national political interests », Balkanologie [En ligne], Vol. VIII, n 1 | 2004, mis en ligne le 21 janvier 2010, consulté le 17 décembre 2020. URL : http://journals.openedition.org/balkanologie/517 ; DOI : https://doi.org/ 10.4000/balkanologie.517 


\section{TURKISH POLICY TOWARDS THE CONFLICT IN KOSOVO : THE PRE-EMINENCE OF NATIONAL POLITICAL INTERESTS}

Sylvie Gangloff*

In February-March 1998, tensions in Kosovo between Albanians and Serbs suddenly rose to an armed level. The appearance of a Kosovo Liberation Army (UÇK, Ushtrica Çlirimtare e Kosovës) had seriously worried the Serbian authorities who decided on several arrests and attacked villages where UÇK fighters were finding - or were supposed to have found - support. Massacres of some Albanians took place and continued sporadically the following year, notably during the summer of 1998 . The international community tried to mediate between the two opposed peoples but without any success. Finally, NATO members, concerned that the Serbian authorities were organizing - or were about to organize - an ethnic cleansing, launched air strikes against the Federal Republic of Yugoslavia (March 1999-June 1999).

During the entire conflict, Turkish leaders did not take major initiatives in the international diplomatic arena. They even refrained, especially during the first phase of the fighting, from commenting on the events and the whole issue did not give rise to passionate political debate (as it had for BosniaHerzegovina). After the decision of military intervention was made by its NATO allies, here again, Turkish military and political leaders looked rather reluctant to invest in this military operation. Turkish leaders did not oppose the intervention (as they did in the case of Greece and Russia for example) but expressed their willingness to remain on the side.

Between 1992 and 1995, the persecution of Muslims in BosniaHerzegovina aroused scandalized reactions in the public opinion in Turkey. The Turks saw - or perceived - their fellow Muslims massacred precisely because of their religion. The war in Bosnia-Herzegovina was extensively commented on in the press and in public declarations, and Turkey exerted a fairly

\footnotetext{
• Chercheur associé au laboratoire d'études turques, CNRS/UMR 8032. (sylvie.gangloff@afebalk.org)
} 
intense diplomatic pressure on the international community by launching initiatives whenever it could in the international organizations to which it belongs (NATO, OSCE, UN, Organization of the Islamic Conference). Moreover, Turkish leaders insisted on the implementation of the decisions of the United Nations, even if this meant a military intervention ${ }^{1}$.

A few years later, in 1998-1999, the conflict between Serbs and Albanians in Kosovo did not at all arouse the same concern and the same scandalized reactions - even though Albanians are almost entirely Muslims and were also subject to Serbian assaults. Concern for massacred fellow Muslims was not as visible, not as widely denounced and not so widely instrumentalized by some Turkish political factions. Turkish officials were extremely cautious in their public declarations on the responsibilities in this conflict and on the suggested diplomatic or military (re)-actions. Indeed, it seems that Turkish officials had some other concerns in mind and that the political and juridical nature of the conflict itself was embarrassing for them. Comparisons between the situation in Kosovo and the situation in South-East Turkey were actually made by some Western leaders here and there. Therefore, whatever the religious aspects of the conflict in Kosovo - or the reality of massacres of civilians - it was a matter of political priorities to stick to the principle of national unity over the claims of some "terrorists " and to the principle of non-interference in internal affairs. The numerous Turks of Albanian origin in Turkey did not play any major political role, nor did - at first - the Turkish minority in Kosovo whose presence and situation aroused interest but which only became a subject of political interest or political maneuvers later in 2000.

\section{A CAUTIOUS DIPLOMACY IN THE BALKANS}

The policy of the Turkish government concerning the conflicts in the Balkans has been very cautious since 1991. The options for Turkey were limited. It could act only in accord with the West, unilateral action was not possible or even wished for (in political or financial terms). It should not be forgotten that Turkey and Turkey's initiatives were carefully watched by the other Balkan countries, suspicious of its real intentions, and prompt to denounce any move on its part. Turkey's long domination of the Balkans sets it up as a suspicious actor in the eyes of most of the countries in the area ; it was against the Ottoman Empire that the Balkan nations forged their independence. This phenomenon of " fundamental enmity "

${ }^{1}$ See Gangloff (Sylvie), « La politique balkanique de la Turquie et le poids du passé ottoman ", in Bougarel (Xavier), Clayer (Nathalie), éds., Le Nouvel Islam balkanique. Les musulmans, acteurs du post-communisme, 1990-2000, Paris : Maisonneuve et Larose, 2001. 
is not a particularity of the Balkans, but what is particular in this case is the inability of the Balkan people to overcome their antagonism.

This historical and emotional background is a serious handicap for Turkey, which has to act cautiously and cannot take any sharp position on the conflicts or tensions in the area. It is still under constant threat of being accused of returning to its warrior-like tendencies, and must therefore act very cautiously ${ }^{2}$. The anti-Turkish policy of Greece in western circles has already had disastrous consequences for Turkey. Moreover the military intervention in Cyprus in 1974 considerably reinforced this perception of a bellicose country, regime, and people. Turkey officially intervened to protect the rights of the Turkish population on the island. This official justification could only raise suspicions in the Balkans that Turkey might put forward the same excuse to interfere in Balkan affairs. This "Cyprus syndrome " is constantly reiterated in the Balkans (in the public opinion, in the press, as well as in public political declarations).

Therefore, Ankara has systematically secured its Balkan diplomacy by the "principles and positions " of the international community and had notably refused to actively participate in military interventions. When NATO issued an ultimatum to Serbia in February 1994, Turkey certainly backed this initiative but proposed its participation in air strikes only for logistic missions 3 . Again, in August 1995 during the operation Delibarate Force, Turkey welcomed the action but the Turkish Air Force did not participate in the actual bombing4.

Turkey has also worked hand-in-hand with Washington in the planning of its regional diplomacy. It was only after the United States got involved in the settlement of the conflict in Bosnia-Herzegovina in 1994-1995 and after it recognized the FYROM (Republic of Macedonia) and signed military agreements with the latter, that Turkey itself took the step of signing military agreements with Macedonia (April 1995 and July 1996) and Bosnia-Herzegovina (august 1995 and January 1996). Again in Spring 1998, when the increasing repression in Kosovo motivated the deepening of the military cooperation between Macedonia and NATO, Turkey, too, strengthened its own military cooperation with Skopje. Like the United States, Turkey supported Albania, Macedonia and the Bosnian-Croat Federation, politically and militarily. Last, Washington and Ankara undertook a collaborative effort to re-arm and train the Croat-Muslim army in the framework of the US " Train and Equip Program " 5 .

\footnotetext{
${ }^{2}$ See Gangloff (Sylvie), "The Weight of Islam in the Turkish Foreign Policy in the Balkans ", Turkish Review of Balkan Studies, (5), 2000/2001.

${ }^{3}$ Milliyet, 11/02/94. A total of 18 Turkish F-16's were stationed in the Ghedi base in Italy to contribute to the implementation of the no-fly zone.
}

4 Turkish Daily News, 31/08/95.

5 The training began in May 1996 in two bases near Ankara. All of the armored units of the Bosnian army have been trained in Turkey. Milliyet, 09/06/97. 
Turkey has also been careful not to cut off relations with the FRY (Federal Republic of Yugoslavia). It had actually kept rather good relations with Yugoslavia during the whole cold War period and these stable relations grew even stronger in the late 70's and in the $80^{\prime} \mathrm{s}^{6}$. After the collapse of Yugoslavia and the irruption of conflicts, Turkish leaders tried not to antagonize Serbia. For example, they waited four months (until May 1992) before recalling their ambassador after Belgrade had done so (January 1992) and during the whole conflict, contacts were maintained at the level of chargé d'affaires. After the Dayton agreement, Turkish leaders quickly renewed their relations with those they previously called "Serbian aggressors ". Indeed, they actively supported Serbian policy after the Bosnian war7. Turkish businessmen, including members of the MÜSIAD ${ }^{8}$, hastened to invest in this country and the agreements regulating trade between the two nations were rapidly concluded. Bosnia does not seem to receive the same attention. In 1997, bilateral trade did not exceed \$25 million.

\section{KOSOVO : ANOTHER DILEMMA FOR TURKEY}

As during the war in Bosnia, Turkey condemned the violence of the repression in Kosovo and proposed its participation in an international peacekeeping force, but, in contrast to its reaction toward the events in Bosnia, it did not display an intense diplomatic activism.

As usual, national interest clearly prevailed over any kind of religious, cultural or historical solidarity. Here again, Turkey could not take any unilateral steps in this conflict and had to act cautiously if it wanted to avoid antagonizing Balkan populations. But another dilemma was added. In the case of Bosnia, the independence of the country was accepted - if not recognized - on the international scene, but in the Kosovo case the entire international community - at least officially and at first - insisted on the territorial integrity of the FRY. In this context, it was / is indeed hard to imagine Turkey supporting a movement of separatism (or one so perceived by the international community) when it was / is fighting a similar movement on its own territory.

\footnotetext{
${ }^{6}$ Jelić (Mirko), Stojiljković (Jerka), Bajić (Danka), "Yugoslav-Turkish Relations, 1976-1988 ", Yugoslav Survey, 30 (4), 1989 ; Ataöv (Türkkaya), "Turkey's Expanding Relations with the CIS and Eastern Europe ", in Dodd (Clement), ed., Turkish Foreign Policy. New Prospects, London : Eothen Press, 1992, p. 114. 7 Some commentators (like Hasan Ünal) have suggested that Turkey wanted to develop cooperation with Serbia in order to avoid a perennial Serbo-Greek alliance. Zaman, og/o6/97.

${ }^{8}$ The MÜSIAD (Müstakil Sanayici ve İsadamlan Derneği) is an association of businessmen openly advocating their link to Islam.
} 
Actually, numerous scholars or politicians made this analogy between Kosovo and Kurdistan (an ethnic minority, in majority in its own area, demanding rights or claiming independence). The Yugoslav ambassador in Ankara, for example, did not miss an opportunity to refer to the fight against the PKK in Turkey (" Turkey should understand Belgrade better than any other country since it is involved in similar situation $" 9$.

Therefore, Turkey did not launch any diplomatic initiative of importance and, at most, has condemned the violence of the repression and has called for a constructive dialogue. Even before the outburst of massacres in the spring of 1998, Turkish leaders were extremely cautious in their Kosovo policy. They had been urged by the Kosovars to help them but they did not respond : As early as 1992, Ibrahim Rugova went to Turkey and asked for recognition; the Prime Minister of the "shadow cabinet ", Bujar Bukoshi, asked Turkey to send observers to the 22 March 1998 elections $^{10}$; Adem Demaçi called on Turkey to be more active in the settling of Kosovo problem ${ }^{11}$; etc. Most of the leaders of Kosovo expressed their disappointment with this " passive policy ", a policy that had been qualified as " pure rhetoric " by the writer Rexhep Oosja ${ }^{12}$.

Very soon after the increase of the repression in Kosovo in March 1998, the former Turkish Foreign Minister went to the FRY (on the 8 March). During this visit, he delivered to President Milošević a letter from Süleyman Demirel, at the time president of Turkish republic, which stated that " Turkey, too, has to fight terrorism on its territory $»^{13}$. During this visit, İsmail Cem asserted Turkey's intention to support FRY's admission to international organizations, and a new bilateral agreement was signed ${ }^{14}$. Last, he went to Kosovo but neglected to meet local Albanian leaders ${ }^{15}$. During the whole course of 1998 , the Yllmaz government remained actually extremely inattentive to the developments in Kosovo, especially during the Serbian military operations during the summer ${ }^{16}$.

The main preoccupation of Ankara is the risk of an extension of the Kosovo conflict to the entire peninsula, and here, "its " national interest is concerned. The scenario most frequently put forward in Turkey (as elsewhere)

9 See the interview he gave to Turkish Daily News, 30/0199.

${ }^{10}$ Anadolu Ajansi, 17/03/98.

${ }^{11}$ Cumhuriyet, 16/10/98.

${ }^{12}$ Qosja (Rexhep), La question albanaise, Paris : Fayard, 1995, p. 233.

13 Tanjug, 08/03/98; Reuters, 09/03/98.

${ }^{14}$ Milliyet, o9/03/98; Hürriyet, o9/03/98.

15 Zaman, og/03/98.

${ }^{16}$ Uzgel (ilhan), " Kosovo : Politics of Nationalism and the Question of International Intervention ", Turkish Review of Balkan Studies, (4), 1998-1999, p. 330. 
has been the fear that if Albanians in Kosovo were granted independence, the Albanians in Macedonia would follow the movement, provoking the disintegration of the Republic of Macedonia and a regional conflict ${ }^{17}$. Turkey immediately strengthened its military assistance to the Republic of Macedonia, where there is a large Albanian community with close links to the Kosovar Albanians, and which was, therefore, the weak point in the containment of the conflict in Kosovo. In June 1998, negotiations were engaged on the delivery of 20 F-5 planes to the Macedonian army and the training of Macedonian pilots in Turkey. In the previous weeks, NATO had organized a " demonstration of force " in Macedonia (the Determined Falcon maneuvers), while the Serbian air force penetrated several times into the contested zone between the two countries. Turkey contributed as well to the NATO naval force stationed in the Albanian port of Durrës ${ }^{18}$, and very early (since the beginning of March 1998), it proposed its participation in a peacekeeping force ${ }^{19}$.

The Turkish press has praised the " realistic approach " of the authorities. The independence of Kosovo was clearly rejected and newspapers even referred to the "energetic intervention " of the international community during the Spring $1998^{20}$. As for the daily Türkiye, of nationalist and Islamist tendencies, it covered this event in a rather dispassionate tone ${ }^{21}$. At this point, contrary to the case of Bosnia-Herzegovina, the issue did not raise much political debate. Nationalist and Islamist media did denounce the massacres of Albanians in Kosovo and criticized the cautious approach of the government, but did not, in any case, instrumentalize the issue for propaganda or electoral motives. The Islamist party (the Fazilet partisi ${ }^{22}$ ), for the same reasons as the government, did not organize massive demonstrations or fund-raising campaigns. And it should be pointed out that Turks of Albanian origins were heavily represented in the central administration of the Fazilet partisi ! However, spectacular information was once in a while published in the Islamist press. One could read, for example, in the edition of 31 August 1998, that Serbs had literally disemboweled young Albanian girls. In the same edition, it is as well stated that the Serbs had installed Russian S-300 missiles in Kosovo, a move that symbolizes high danger in Turkey with the - at the time - ongoing contro-

\footnotetext{
${ }^{17}$ See, for example, Cumhuriyet, 19/06/98.

${ }^{18}$ This NATO force was composed of one ship each from Turkey, Italy, Spain and Macedonia. Anadolu Ajansi, 09/07/98.

19 This participation was approved by the Turkish parliament in October 1998.

${ }^{20}$ Cumhuriyet, 13/03/98; Milliyet, 08/07/98, 11/03/98.

${ }^{21}$ See for example, "An active diplomacy in Kosovo ", Türkiye, 07/07/98 ; "Last warning to Milošević ", Türkiye, 24/09/98; " 20000 Kosovars flee their villages ", Türkiye, 31/07/98.

${ }^{22}$ In January 1998, the Islamist party, Refah partisi, was dissolved under the decision of the constitutional court. Another Islamist party, the Fazilet partisi, was immediately created.
} 
versy on the deployment of Russian S-300 missiles in Cyprus. However, as usual (as it had been the case for the conflict in Bosnia-Herzegovina), some editorials were more vindictive ${ }^{23}$. They vigorously denounced the new ethnic cleansing, the inaction of the international community and the new orthodox plot and, for some of them, openly advocated the independence of Kosovo. Of course, the massive massacres undertaken by the Serbian authorities during the course of Spring 1999 revitalized in all the newspapers the image of Serbs as " ethnic cleansers" " " murderers " and " butchers ".

But Turkish leaders maintained their commitment to the preservation of the territorial integrity of the FRY and were extremely reluctant to intervene in the internal affairs of Kosovo. To reject the parallel with the situation in the southeast of Anatolia, they put forward two kinds of arguments :

1 - The repression in Kosovo was on such a large scale that no comparison was possible. President Demirel even called this repression a " genocide $"^{24}$.

2 - The nature of the conflict was completely different. " They call them a minority in Kosovo but we do not have minorities in Turkey ", declared Süleyman Demirel25.

Turkish leaders were backed, in this approach, by most of the editorialists : " There is no other state that commits such violence against its own population on its own territory (...) The war between the Serbs and the Albanians is both an ethnic and religious confrontation ${ }^{26}$.

Turkish leaders officially advocated the " restoration " of the rights of the Albanians ${ }^{27}$. By insisting on the restoration of the rights of the Albanians in Kosovo, the Turks avoided any unwelcome comparison with the Kurds (who never had any rights in the past such as those enjoyed by the Albanians in Kosovo under the 1974 Yugoslav Constitution).

Here again, Turkey has followed the path of the United States. The Turkish air force participated in NATO air strikes on the FRY ${ }^{28}$ and after June 1999, as it had announced very early on, it contributed to the international peacekeeping force stationed in Kosovo. Around 1 ooo Turkish soldiers were deployed in

23 See for example Necati Özfatura in Türkiye, 10/04/98, 05/08/98, 06/08/98. Comments on Kosovo of one of this famous editorialist of Türkiye, had been compiled and published at the end of 1998 : Özfatura (Necati), Hedefteki Ülke. Kosova [Kosovo. A Threatened Country], İstanbul : İci, 1998.

24 Hürriyet, 13/04/99.

25 Anadolu Ajansi, 28/04/99.

${ }^{26}$ Milliyet, 26/03/99.

${ }^{27}$ In the proposal the Turkish government made on 16 March 1998 to halt violence in Kosovo, they expressly recommended " restoring the rights of all ethnic groups in Kosovo, which they enjoyed at the time of Kosovo's autonomy n. Turkish Daily News, 17/03/98. President Demirel talked as well of the "restoration of fundamental rights and freedoms of Albanians in Kosovo n during his official visit to Albania in mid-July 1998. Albanian Telegraphic Agency, 15/07/98.

${ }^{28}$ A total of 11 F-16's planes were stationed in the Ghedi base in Italy. 
Kosovo in July 1999. They are stationed around in Southwestern Kosovo (German sector) where the Turkish community predominantly lives. Around a hundred Turkish policemen were also sent to participate in the "Interim Civil Administration ${ }^{29}$. Last, Turkish coordination offices were opened in Priština and in Prizren in July 1999 during İsmail Cem's visit ${ }^{\circ}{ }^{\circ}$. Officially, they were mandated to coordinate the distribution of Turkish humanitarian assistance in the province.

Even when a representative of the UÇK, Shaip Muja, came to Istanbul, the visit was carried out at a time when the United State had recognized the UÇK as a partner in the negotiations. Nothing was said about the contacts he made in Turkey, but this trip was officially made to visit six UÇK fighters who were under treatment in a Turkish hospital, a convenient way to visit with the least possible diplomatic visibility. In the interviews he gave, Shaip Muja remained rather cautious on his opinion on Turkish policy toward Kosovo ${ }^{31}$.

More surprisingly, Turkey finally participated in the actual bombings during the NATO strikes. This represented a noticeable change in the line followed during the conflict in Bosnia-Herzegovina, and reactions in the Turkish press were rather mixed ${ }^{32}$. Turkish leaders themselves were somewhat embarrassed and rumors spread in the press before confirmation in mid-May $1999^{33}$. A month earlier, Bülent Ecevit, the former Prime minister, was categorically denying Turkey could participate in offensive missions 34 , and most analysts did not expect Turkey to do so 35 . Turkey probably wanted to strengthen its positions within the Alliance, and this, several weeks after the Washington summit where it had to fight hard against the French-English proposal to establish a European Identity of Defense and Security, which would have marginalized it. A few days earlier, the Turkish cabinet had also approved the NATO request for using Turkish bases during the air strikes ${ }^{36}$.

\footnotetext{
29 " Report of the Secretary-General on the United Nations Interim Administration Mission in Kosovo ", S/2000/1196, December 15, 2000. See as well Milliyet, 09/04/00, Türkiye, 22/10/00.

30 Türkiye, 22/10/00 ; Anadolu Ajansi, 28/07/00.

31 Tepeli (Selçuk), "Sirplar'ı destekleyen Türkler " [These Turks who support the Serbs], Aktüel, 21/01/99.

${ }^{22}$ See, for example, the editorials of İter Türkmen, Hürriyet, 27/05/99 and Sedat Ergin, Hürriyet, 21/05/99.

33 Reuter, 16/05/99. The public was informed in an interview given by the president. See Hürriyet, 21/05/99.

34 Cumhuriyet, 04/04/99; Anadolu Ajansi, 04/04/99. See as well, for example, Ismail Cem (press conference) : " Turkish planes are carrying out a defensive mission. There is no single indication that Turkish planes will exceed this concept ". Anadolu Ajansi, 25/03/99.
}

35 Turkish Daily News, March 25, 1999; Johyon Naegele, RFE/RL Features, April $1^{\text {st }}, 1999$.

${ }^{36}$ Turkish Daily News, May 22, 1999 ; Gazeta 55, May 14, 1999. 
When Albanians were massively expelled from Kosovo, Turkey opened its doors to them. This is actually a constant component of the Turkish Republic's policy toward Turkish and Muslim communities in the area : it had accepted, almost without any restriction, refugees and immigrants from the Balkans (Turks from Bulgaria in the beginning of the 50's and in 1989, Albanians from Yugoslavia in the 50's and the 6o's, Muslims from BosniaHerzegovina after 1992, etc.). The only exceptions were due to the very impossibility to settle them, as when 350000 Turks from Bulgaria poured in Turkey in 1989. A total of 18000 Kosovars officially came to Turkey from the end of March 1999 to June 1999. Almost half of them were settled in the Kurklareli camp in Thrace ${ }^{37}$, which had been built for the Bulgarian Turks who arrived in 1989 and later used for the Muslims from Bosnia-Herzegovina. All of these Kosovo Albanians returned to Kosovo during the Summer 1999. The Turkish Red Crescent also set up two tent cities for refugees, one in Macedonia (Boyane) and one in Albania (Elbasan).

Last, a new discourse appeared at the beginning of the NATO strikes. The claim to an Ottoman legacy, which had been previously exclusively made by nationalist and Islamist circles ${ }^{38}$, emerged in official discourses. The claim to an Ottoman legacy in the identity and the history of the Turks has become more and more pronounced these past years, but, in general, official discourse tended to avoid any reference to this (common) heritage when the Balkan people - and conflict - were concerned 39 . In the Kosovo case, President Demirel finally mentioned the " duty to save our Kosovar brethren " 40 and the " historical and moral responsibility of Turkey $"^{41}$; Ismail Cem pointed to the " 500 years experience in Kosovo $"^{42}$; and former Prime Minister Bülent Ecevit stated that " the Kosovars are our brothers and the legacy of our history " 43 , " the heritage presented to us by history $" 44$. Turkish leaders were probably

37 In mid-1999, 7600 Albanians out of an official total of 17500 had been settled in Kirklareli. Anadolu Ajansi, 04/06/99.

${ }^{38}$ See, for example, about Kosovo, "The orphans of the Ottoman Empire claim their rights ", Zaman, $19 / 10 / 96$; or the editorialist of Türkiye, Necati Özatura, who almost systematically referred to the Ottoman Empire in his numerous articles on Kosovo.

39 Several publications have emphasized this - still visible - Ottoman heritage in the Balkans. Hasan Mercan (a Turk from Kosovo) has published, in the editorial houses of official Turkish foundations, several books on Turkish poetry in Kosovo ; Raif Virmiça has published books on Ottoman architectural monuments in Kosovo (see, for example, Virmiça (Raif), Kosova'da Osmanlı Mimari Eserleri, Ankara : Kültür Bakanliğı, 1999 ; Kosova Hamanlar, Ankara : Kültür Bakanlığı, 2002); etc.

$4^{\circ}$ Anadolu Ajansi, 08/04/99.

${ }^{41}$ Anadolu Ajansi, 01/04/99.

$4^{2}$ Anadolu Ajansi, 04/04/99.

43 Declaration of Prime Minister Ecevit during his visit to the Kurklereli camp. Hürriyet, 08/04/99.

${ }^{44}$ Akșam, 08/04/99. 
trying to justify their participation in the strikes. But, more important, this discourse also appeared during the electoral campaign for the legislative elections (18 April 1999). Actually, the beginning of NATO strikes and massive expulsions of the Albanians from the Kosovo province fell right in the middle of this electoral campaign. It motivated, of course, some competition among Turkish politicians. Tansu Çiller (leader of the conservative party Doğru Yol Partisi) criticized the government for its " apathy over Kosovo "45, Prime minister Ecevit visited the Kırklareli camp a few days before the elections ${ }^{46}$, etc. In addition, the fear that the Islamist party (the Fazilet Partisi) would gain a lot of votes - it had received $21,3 \%$ of the votes in the previous elections, which had led to constant political crisis - incited the " secular " politicians to compete with the Fazilet in terms of solidarity with the oppressed brothers. Indeed, as it had been the case during the conflict in Bosnia, but to a much lesser extent, because of feared comparison with the situation in South-East Anatolia, the Kosovo conflict was used by the Islamists as a political platform.

\section{THE ALBANIANS IN ISTANBUL : A LOBBY FOR THE KOSOVO CAUSE ?}

The Turks of Albanian origin were mobilized and fairly active in their lobbying for the Kosovo cause. Most of these Albanians settled in Istanbul in the 50's and the 6o's. Under the agreement signed between Yugoslavia and Turkey in 1953, Turks from Yugoslavia could immigrate to Turkey. As a consequence, many Albanians declared themselves Turks and moved to Turkey ${ }^{47}$. Around 150000 " Turks " immigrated to Istanbul at the time ${ }^{48}$, although most immigrants of Albanian origin question this figure 49 . They settled in areas where the Albanians who migrated in the 3o's lived (Bayrampașa, Aksaray, KüçükÇekmece).

45 Milliyet, 28/01/99.

${ }^{46}$ Milliyet, 07/04/99; Akşam, 08/04/99.

${ }^{47}$ As the 1953 census in Yugoslavia shows, many Albanians declared themselves Turks. The number of " Turks " in Yugoslavia therefore officially rose from 97954 in 1948 to 259535 in 1953.

${ }^{4}$ See Cevat Geray, probably the most reliable source on immigration from the Balkans to Turkey. Geray (Cevat), Türkiye'den ve Türkiye'ye göçler ve göçmenlerin iskanı (1923-1961) [Les migrations de Turquie et vers la Turquie et l'installation des migrants], Ankara : Ankara Üniversitesi Siyasal Bilgiler Fakültesi Yay., 1962.

49 Kut (Șule), "Turks of Kosovo: What to Expect n, Perceptions, 5 (3) [available on the internet at : www.mfa.gov.tr/grupa/percept/V-3/skut-4.htm]. 
Numerous associations represent this community in Istanbul50. Most of them were created in the 50's and 6o's for cultural and social reasons: to help new emigrants find lodging and work, to organize folk festivals, etc. After 1990 , some of these " folkloric associations " began to have political preoccupations. Some, like the "Association of the Kosovars ", set up in 1994, have explicit political orientations. This latter association is fairly active in its lobbying for Kosovo, organizing meetings with Turkish deputies and officials, diffusing its message to the press, etc..$^{1}$ When a repression campaign was launched in Kosovo in February 1998, these Albanian associations immediately mobilized, organizing two demonstrations in Istanbul : the first on 8 March, a few days after the beginning of the repression, the second two month later. To reinforce their support campaign, fifteen of these associations also set up a " Kosovo Information Commission " in May $1998^{52}$, whose aim was to coordinate their initiatives and to lobby the press 53 . In addition, a representative office of the Republic of Kosovo in Istanbul was inaugurated in December 1996. This opening did not receive, of course, any official authorization. However, according to Kosovo Daily Report ${ }^{54}$, Albania's ambassador to Turkey, the Minister of Information of the Republic of Kosovo and the vice-chairman of the Democratic League of Kosova attended the opening ceremony. This representative office of the Republic of Kosovo seems to be closely linked to the LDK ${ }^{55}$.

Despite the active mobilization of their " leaders ", the Albanian community itself did not really take part in this lobbying. These Albanians are in fact generally " turkified ", and most do not speak Albanian anymore. For example, there is today no specific community press (neither in Albanian nor in Turkish) in Istanbul ${ }^{56}$. They definitely do feel concerned about the fate of their fellows in Kosovo and they have some kinship for the Albanians ; however, this does not mean that they are ready to assume any particular personal - political or financial - engagement for Kosovo. According to the words of the leader of one of the most influential Albanian groups, the "Turkish-Albanian

$5^{\circ}$ For example :Shoqata e gjilanasve ; Kosovalılar Kültür ve Dayanıșma Derneği / Shoqata e kosovarëve (Aksaray) ;Priștineliler Kültür ve Dayanıșma Derneği / Shoqata e prishtinasve (Bayrampașa) ; Prizrenliler Dayanıșma ve Kültür Derneği / Shoqata e prizrenasve (Fatih) ; Türk-Arnavut Kardeșliği Kültür ve Dayanıșma Derneği / Vëllazëria Shqiptaro-Turke (Bayrampașa) ; etc. See Rapper (Gilles de), Les Albanais à Istanbul, Istanbul : IFEA (coll. « Les dossiers de l'IFEA n), 2000, pp. 22-23.

${ }^{51}$ Rapper (Gilles de), op.cit., p. 13.

${ }^{2}$ Anadolu Ajansi, 11/05/98.

53 This commission dissolved itself a year later.

54 Kosovo Daily Report, 26/12/96.

55 Rapper (Gilles de), op.cit., p. 20.

${ }^{56} \mathrm{~A}$ journal, Besa, was published every two months by the Türk-Amavut Derneği but its political content seems not to have suited the Turkish-Albanian community. It lasted from 1993 to 1996. 
Association "(Türk-Arnavut Derneği), the mobilization of the Turkish population of Albanian origin was rather disappointing57. The participation in the two demonstrations organized by the leaders of this community during spring 1998 was quite $l o w^{58}$, and when the " ethnic cleansing " campaign was launched in March 1999, money collected for humanitarian purposes by the Albanian associations was rather poor 59 . The Turkish Albanians did not, of course, join the $U C \mathrm{C}^{60}$. However, during the spring of 1999, they assisted the refugees by lodging some of them in their houses or by preparing their country house beside the camp of Kirklareli in Thrace to accommodate them ${ }^{61}$.

Moreover, even if mobilized, leaders of these associations keep a low Kemalist profile. First, they have completely integrated, and propagate, the official discourse of a tolerant, multicultural, and westernized Turkey. Second, these associations are generally financed by conservative parties. In any case, they are careful to isolate themselves from the Islamist milieu that tries to use their cause as a political platform. Therefore, even if they openly advocate the independence of Kosovo ${ }^{62}$, they understand very well that Turkey has some national priorities. Two months after İsmail Cem's trip to the FRY in March 1998, Kamil Bitiș, the chairman of the "Kosovo Information Commission ", even described İsmail Cem's attitude as " very positive "63.

The Turkish government has kept to its previous and official line and has not supported the initiatives of these associations. The two demonstrations organized during Spring 1998 were not authorized, nor was the inauguration of the representative office. On $8 \mathrm{March}$, the police barred the route to the Yugoslav Consulate, the destination of the demonstrators. But a few signs indicate that the authorities took advantage of this network to make contacts that might one day be useful. For example, the opening of the representative office of the Republic of Kosovo in Istanbul did not received any official backing and no member of the government attended ${ }^{64}$, but nothing was done to prevent this inauguration of which the Foreign Ministry was well informed. A

57 Interview with Halil Metin, president of the Türk-Arnavut Derneği, August 29, 2000.

$5^{8}$ The first demonstration (March 1998) gathered around 6000 people according to the press (Turkish Daily News, 09/03/98), 2000 according to the official press agency (Anadolu Ajansi, 09/03/98) and from 8 to 10000 according to the organizers. As for the second demonstration, it was even less popular.

59 Interview with Halil Metin, August 29, 2000.

60 To the exception of the Albanians recently arrived from Kosovo. Interview with Halil Metin, August 29, 2000.

${ }^{61}$ Rapper (Gilles de), op. cit., p. 20.

${ }^{62}$ See for example, "Kosova Cumhuriyeti 6 yașinda ", Besa, (7), July 1996.

${ }^{63}$ Anadolu Ajansi, 11/05/98.

64 The ceremony was held in a Hotel in Istanbul on the $20^{\text {th }}$ of December. 
few leaders of political parties also attended the demonstrations. During the demonstration of the $8 \mathrm{March}$, the ANAP (Anavatan Partisi) even dispatched an electoral bus to the route of the demonstration ${ }^{65}$.

\section{THE TURKISH MINORITY IN KOSOVO}

One of the constant lines of Turkish policy toward Kosovo is the insistence on the participation of the Turkish minority in the peace talks. The Serbs fully subscribed to this request, which allowed them to break the Albanian unity in Kosovo. For the same purpose, Belgrade granted many cultural rights to the Turks in the 6o's and 70's. After the 1968 revolt in the province, Belgrade supported the publication of several newspapers in Turkish ${ }^{66}$, and Turkish was listed as an official language in the 1974 Constitution. Later on, in 1985, a department of Turkish studies opened at the University of Priština. In the mid90 's, around 50 students were registered in this department ${ }^{67}$. This policy continued after the abolition of Kosovo's autonomy in 1989 : the Albanian language, but not Turkish, was banned from broadcasting of the official Radio Television; Albanians lost their jobs, but not the Turks ${ }^{68}$.

This Turkish minority numbers around 12000 according to the 1991 census ( $0,6 \%$ of the total population of the Kosovo province), but the Kosovo Turks claim that they number at least 60000 . This figure is also widely quoted in official and unofficial Turkish sources ${ }^{69}$. They claim that the 1991 census is not reliable due to political manipulations and that the number of Turkish speakers is even much larger. Indeed, ethnic identities are rather complex and unclear in the area, the practice of shifting identities widespread. No definite

65 Turkish Daily News, 09/03/98.

${ }^{66}$ Details of these publications can be found in Bartlett (C.N.O.), " The Turkish Minority in Yugoslavia ", Bradford Studies on Yugoslavia, (3), 1980, pp. 11-12.

${ }^{67}$ For details of number of students in Turkish language (from primary education to university), see Tunalıgil (Cemali), " Yugoslavya'da Türk dilinde eğitim - öğrentim (1951-1997) n [Education and teaching in Turkish in Yugoslavia - 1951-1997], Türk Dünyası Tarih Dergisi, (134), février 1998.

${ }^{68}$ Kut (Șule), op. cit.

${ }^{69}$ Here are, for example, a few example of these estimates : 60 o00 Turks and 200000 Turkish speakers according to the president of the Türk Demokratik Birliği (Anadolu Ajansi, 18/03/99) ; 20000 according to the permanent Turkish representative to NATO, Onur Oymen (Turkish Daily News, 25/03/99) ; 40 to 50000 according to Tekin (Arslan), Balkan Volkan1, Istanbul: Ötürken, 1993, p. $300 ; 20$ to 40 000 according to the Turkish Foreign Ministry (declaration of the FM speaker, Mehmet Atancall, 24 March 1999). The UN High Commissioner for Refugees estimates this population at around 20 ooo. Kosovar Albanians claim that the real figure is much smaller. Radio 21, 31/07/00, quoted by Albanews, 01/08/00. 
estimate can thus be made, opening a vast margin to various political claims. According to the 1991 census, there are 7227 Turks in the area of Prizren (the location of the village of Mamuša which is inhabited by Turks ${ }^{70}$ ), 887 Turks in Gilan ${ }^{71}$ in the east of Kosovo, 445 Turks in Mitrovica (in the north of Kosovo) ${ }^{72}$ and 1986 Turks in Priština. In Turkish sources, the village of Dragaš is sometimes also said to be inhabited by Turkish people. In reality, these Muslims, the Gorans (Goranci), speak a Slavic language but Turkish sources tend to assimilate this population to Turks 73 .

This is, here, a typical case of a minority squeezed between a majority (the Serbs in the RFY) and " a minority in majority " in its own province (the Albanians), fighting to get some rights. These Turks would be more comfortable in a multicultural society - and a federal administrative structure - than in a country dominated by Albanian nationalists. In sum, they are concerned with their long-term viability in Kosovo as an ethnic group. Their relations with the Albanians are therefore tainted with suspicions. On the other hand, Albanians view the " pro-Turkish policy " of Serbian authorities as an " evil alliance ". The Albanians notably accuse the Turks of having " collaborated " with the Serbs during the 1999 massacres and expulsions.

On the whole, the legitimate claims of the Albanians are viewed by some of these Turks as a threat of Albanization. Other Turks, however, feel close to their persecuted Muslim co-religionists. Actually, numerous Turks have been Albanized in the past twenty years. Besides regular marriages between Albanians and Turks, the Albanians, who - as the Turks - obtained some rights under the 1974 Constitution, put pressure on the Turks, or even had an antiTurkish policy ${ }^{74}$. The Kosovar Turks are therefore represented by two political parties :

- the Turkish Democratic Union (Türk Demokratik Birliği, TDB)75, which is opposed to an Albanian domination and often perceived as pro-Serb, or, in any case, closer to the Serbs. For example, it opposed the boycott of the official (FRY) elections and schools after 1990. It is actively lobbying for the restitutions of

\footnotetext{
$7^{\circ}$ The Turkish Task Force stationed in Mamuša seems to be rather involved in the life of the local Turkish community. It has organized meals for the Iftar during Ramadan, organized courses in mechanics for the locals, and so on. See, for example, KFOR News Update, 03/01/01, 12/01/01.

${ }^{71}$ Gilan in Turkish, Gnjilane in Serbian, Gjilan in Albanian.

${ }^{72}$ The Turkish Community of Mitrovica has gathered under the common roof an NGO and later on (in July 2001) joined the Turkish Democratic Union. Anadolu Ajansi, 29/07/01.

73 The same confusion is sometimes made in Turkish press concerning the Slavic Muslims in Macedonia (the Torbeș). But, for example, the Pomaks in Bulgaria and Greece are not subject to any " Turkification tendencies $n$ in the press (except for a few nationalistic publications).

74 Kut (Șule), op. cit.

75 The Turkish Democratic Union (TDB) became the Turkish Democratic Party (KTDP) during the Summer of 2001.
} 
the rights that the Turks were granted under the 1974 Constitution, and notably the restoration of Turkish as an official language since the UNMIK did not recognize it ${ }^{76}$.

- The Turkish Popular Party (Türk Halk Partisi) is, on the contrary, close to the Albanians. It presented candidates at the "illegal " local elections of 22 March 199877 and it is opposed to the restitutions of the rights of the Turks. It is sometimes referred to, in the Turkish press, as the party of the " Albanized Turks ${ }^{78}$. This party is said to be close to the LDK leader, Ibrahim Rugova. Its support in Kosovo is, however, much less higher than its counterpart - and opponent - the TDB. For example, it failed to gather the required 1000 signatures in order to be qualified for the November 2001 general elections79.

The TDB lobbying is directed at the UNMIK administration as well as at Turkey. A TDB delegation came to Ankara in July $2000^{80}$ and obtained the backing it sought. The former Turkish Foreign Minister, İsmail Cem, sent a letter to the UN special representative in Kosovo, at the time Bernard Kouchner, pleading for the recognition of Turkish as an official language, and even threatened to withdraw Turkish support to Kosovo if " the political and cultural rights of the Turkish minority were not protected ${ }^{81}$. Turkey also exerted its support for the rights of this minority within NATO through its permanent representative to this organization ${ }^{82}$.

However, the extremely tense relations between the Turks and Albanians within the province put Turkey in a rather awkward position and prevented it, on the ground, from actively standing by the Turks. Turkish leaders repeated several times, for example, that no discrimination would be made between Albanians and Turks in the distribution of Turkish humanitarian assistance. The Kosovar Turks expressed several times the wish that Turkey finance education in Turkish in the area, open a cultural center in Prizren, or grant them a status of double nationality. Except for the Turkish Red Crescent (Kzzlay), it seems that only the official Turkish religious affairs directory (Diyanet) has been active in the area. The Diyanet has awarded several scholarships and,

\footnotetext{
${ }^{76}$ For example, forms for the elections were printed in English, Albanian and Serbian, as these were recognized as official languages since Rambouillet.
}

77 Enter (Albanian Independent Press Agency), 22/03/98.

$7^{8}$ It is apparently notably opposed to the addition of Turkish in registration forms for the elections. Türkiye, 01/10/00.

79 KosovaLive, 07/09/01, 28/0901.

80 This delegation was received by the Prime Minister and by the Foreign Minister. Anadolu Ajansi, 27/07/00 ; Türkiye, 28/07/00 ; Turkish Daily News, 27/07/00.

${ }^{81}$ Turkish Daily News, 05/08/00, 21/09/00.

82 See, for example, the diplomatic initiative taken by this representative, Onur Öymen, in March 1999. Anadolu Ajansi, 04/03/99. 
since 1991, quite a few Kosovo Turks enrolled in Islamic studies in Turkey's Imam Hatip Lisesi ${ }^{83}$. Other initiatives have been taken by private institutions or organizations. For example, Turkish business association have made several donations (materials for students in Mamușa, sugar and flour, and so on). The nationalists represented in Turkey by the Millet Hareket Partisi (MHP) and its youth organization, the Ülkü Ocaklar, are somewhat active in the area and the Ülkü Ocakları has some representatives in Kosovo ${ }^{84}$. The Türk Dünyası Araștirmalar Vakfi has organized the education (in Turkey) of numerous Kosovo Turkish teachers since 1991. Leaders of the Turkish Democratic Union/Party (TDB/ KTDP) have close links with this nationalist foundation ${ }^{85}$. Finally, the Aydmlar Ocaklarl (the Hearth of the Enlightened) which represents, this time, the Turk-Islam synthesis ideology ${ }^{86}$ opened a center in Priština. These institutions and organizations, although unofficial, have close links with Turkey's leadership. For reasons mentioned above, Turkey's leaders remain reluctant to take official diplomatic initiatives ${ }^{87}$.

The international administration in Kosovo gradually granted the rights claimed by the TDB. When Bernard Kouchner came to Ankara at the end of July 2000 , a representative of the TDB was invited to participate in the talks (but not of the THP ${ }^{88}$. Two month after, on 15 September, in a letter addressed by Bernard Kouchner to the TDB president, Turkish was recognized as an official language in the province ${ }^{89}$. In this letter, Kouchner stated that UNMIK guarantees the Kosovar Turkish community's rights as referred to in the 1974 Yugoslav Constitution, that the UNMIK regulations will be issued as well in Turkish in areas inhabited by Turkish communities, that identity cards with important information in Turkish will be issued and that in the municipalities where Turkish communities live, instruction in Turkish will be offered. Two

83 Speech of Müveddet Bako (Türk Demokratik Birliği Partisi), Türk Dünyası Tarih Dergisi, (105), September 1995, pp. 9-11.

84 Sanșın (Mehmet), “ Kosova'daki Türk Dünyası ", Sabah, 06/05/97.

85 It should be noted that Turks living in the United States and close to the TDA are as well involved in various humanitarian, cultural, or political initiatives in Kosovo.

86 The Türk-Islam synthesis emphasizes the very fruitful marriage of Islam and Turkism. This ideology has been adopted by the extreme right in Turkey.

${ }^{87}$ This « semi-official diplomacy " (the use or instrumentalization of various associations, foundations or private institutions), is a recurrent tool of Turkish foreign policy, especially in the Caucasus (and notably in Azerbaijan and Chechnya) and in Central Asia, where nationalist or panturkist groups have been used to make contacts and ensure good, but discrete, political relations.

${ }^{88}$ Radio 21, 31/07/00, quoted by Albanews, 01/08/00.

89 Türkiye, 21/09/00, 29/10/00. Although Turkish had been recognized as an official language on 15 September, the TDB did not participate in the 28 October elections because - according to the Turkish Foreign Ministry - the UN mission " failed to take the necessary steps in time ". Türkiye, 29/10/o0 ; AFP, 05/11/00. 
months after this recognition, the leader of the Turkish Democratic Union, Mahir Yagcilar, was appointed to the Interim Council9o. The International Peacekeeping Force (KFOR) had already started to broadcast in Turkish in December 1999 and a Turkish weekly, Yeni Dönem, has been published since then ${ }^{91}$. The aim of the international interim administration of Kosovo is clearly to ensure the participation of all Kosovo communities to the administration of the province. And progress has definitely been made with regards to the claims of the Turks. Problems still regularly occurred. For example, during the 2000 municipal elections, the Turkish community decided to boycott the registration process organized by the OSCE because the forms were not in their native language. But an agreement was finally reached with the Kosovo Turkish leaders and they registered for the November 2001 general elections ${ }^{92}$.

\section{CONCLUSION}

Turkey did not make any significant contribution to settle the conflict in Kosovo. The fear of a parallel with the situation in southeast Anatolia prevented it from exerting diplomatic pressure, as it had been the case in the first phase of the conflict in Bosnia-Herzegovina. But Turkey was as well, and as it had been the case for Bosnia, careful not to antagonize Balkan populations highly sensitive to any Turkish interference in the area. Last, Turkey is not such an important actor in the Balkans and, in any case, its influence remains in the shadow of the US and Europe.

Its position has been fairly constant: it supports the maintaining of Yugoslav territorial integrity and demands enhanced autonomy for Kosovo with maximum rights for all the ethnic groups, including the Turkish community. Turkish leaders, for example, vigorously opposed the UN plan outlined in June 1999. Their main objection was the division of Kosovo into various sectors, which, according to Ecevit, might lead to a deadlock. In addition, political consultations have been launched in February 2001 with a view to renewing ties with the FRY. The Yugoslav Deputy Foreign Minister came to Ankara in February 93 and İsmail Cem, former Turkish minister of Foreign Affairs, was in

\footnotetext{
$9 \circ$ Anadolu Ajansi, 13/12/00.

${ }^{1}$ Akșam, 09/12/99.
}

92 The UNMIK used some mobile registration teams which went to Turkish villages. KosovaLive, 16/01/01, 25/06/01, 28/07/01 ; "Report on the Secretary-General on the UN Interim Administration Mission in Kosovo ", UN Security Council, 07/06/01 ; " Greek Helsinki Monitor Report on the Judicial System, Freedom of the Media and the Situation of Minorities in Kosovo n, IHF Mission to Kosovo, February 2001.

93 Cumhuriyet, 08/02/01; Milliyet, 21/02/01. 
Belgrade at the beginning of March. He signed an agreement on cooperation with the Yugoslav Foreign Ministry and an investment deal. This visit, the first official visit of a Turkish Foreign Minister to Belgrade since 1992, is seen as a turning point in bilateral relations ${ }^{94}$.

The weight of internal affairs, if not in Turkish initiatives then at least in official discourse, is more than noticeable. This was already the case for Bosnia-Herzegovina. Tansu Çiller, former Prime Minister, traveled twice to Sarajevo : in February 1994, a few weeks before local elections, and in November 1995, again four weeks before elections. However, if the Islamists used the Kosovo conflict to publicize their message, they remain rather cautious in this instrumentalization ; here again, because of the "Kurdish parallel " but also because, in the case of Kosovo, the international community - and first of all the United States - did intervene, and strongly, to assist the persecuted Albanians/Muslims. The usual rhetoric of the West applying a " double standard " and letting the Muslims be killed because they were Muslim could therefore not be applied. For the same reason, the "Muslim world " did not mobilize for Kosovo (as opposed to Bosnia-Herzegovina). In addition, the Bosnian experience was rather disappointing. This conflict ended with a pax Americana and the Bosnian Muslim leaders quickly chose between the alliance with the United States and with the Muslim world (mainly Iran where they had their best connections even before the war and whose military assisted them). This rather passive attitude of the Muslim world was of course indicated by several editorialists in Turkey 95 .

Conflicts bearing religious connotations are, in any case, problematic for Turkey. It can make use of the "Islamic " discourse only in moderation. Beyond the traditional suspicion toward the Turks in the Balkans, its secularism and its aspiration to be recognized as a fully westernized country forbids Turkey to raise the Muslim banner as soon as its political interests are concerned. In this respect, the manifestation of conflicts with religious connotations - Christians against Muslims - represents a challenge for Turkey. If it publicly sides with the Muslims, this can only reinforce its image of a Muslim state and therefore cut it off from Europe. Therefore, if " historical ties and responsibilities " and " moral commitment towards Muslim Albanians " have been put forward, Turkish leaders have been careful to reject the idea of a confrontation between Christians and Muslims : "It is not a fight of Slavic Orthodox Christians on one side and Muslim Albanians on the other (...) There is no such thing as MuslimOrthodox confrontation ${ }^{96}$.

94 Hürriyet, $03 / 03 / 01$.

95 For example, " Where are our Muslim brothers ? ", Milliyet, 08/04/99.

96 Süleyman Demirel, in Pulse of Turkey, 27/03/99 (available on internet : www.turkpulse.com/icindekiler.htm) 